\title{
CENTRIFUGATION METHODOLOGY TO EXTRACT SOIL SOLUTION
}

\author{
Método para extração da solução do solo por centrifugação
}

André Somavilla ${ }^{1 *}$; Alexandre Dessbesell2; Danilo Rheinheimer dos Santos ${ }^{3}$

\begin{abstract}
${ }^{1}$ Master Student; Department of Soil; Federal University of Santa Maria, Santa Maria - RS - Brazil; *Corresponding author: somavillaa@gmail.com.

${ }^{2}$ Master Student; Department of Soil; Federal University of Santa Maria, Santa Maria - RS - Brazil; dessbeselale@gmail.com.

${ }^{3}$ Teacher; Department of Soil; Federal University of Santa Maria, Santa Maria - RS - Brazil; danilonesaf@gmail.com.
\end{abstract}

Artigo enviado em 26/05/2017, aceito em 24/08/2017 e publicado em 29/09/2017.

\begin{abstract}
The quantification of ions and compounds present in the soil solution is extremely difficult and requires standard extraction and quantification techniques. The present work describes in detail the equipment and procedures required to extract the soil solution by the centrifugation method of deformed soil samples and analyzes its application in soils with different granulometry. This description of centrifugation method and the Centrifuge 1.0 software are useful tools to all researchers that desire a quickly and economically method to obtain the soil solution. We emphasize that there is no consensus on the best method of obtaining the soil solution, but is clear the need for the researchers to explain how they obtained it.
\end{abstract}

Keywords - Spin Movement; G-force; Extraction Energy; Centrifuge.

Resumo - A quantificação de íons e compostos presentes na solução do solo é extremamente difícil e requer técnicas de extração e quantificação padronizadas. O presente trabalho descreve detalhadamente os equipamentos e os procedimentos necessários para extração da solução do solo pelo método da centrifugação de amostras de solo deformadas e analisa sua aplicação em solos com diferentes granulometrias. A descrição da técnica e o programa Centrifuge 1.0 são ferramentas úteis para os pesquisadores que desejam um método rápido e barato. Destaca-se que não há um consenso sobre o melhor método para se obter a solução do solo, o que está claro é a necessidade dos pesquisadores explicitarem a forma como foi obtida a solução do solo.

Palavras-chaves - Movimento de rotação; Força G; energia de extração; Centrífuga.

\section{INTRODUCTION}

The quantification of ions and molecules present in solution requires the separation of them from the soil matrix. Several techniques of soil solution extraction are suggested in literature. Some of which are conducted in situ; for instance, the method with suction cups, used by STRECK et al. (2004) (with undeformed structure). And, others with deformed structure realized in laboratory: porous capsules (CARMO et al., 2016), centrifugation (DAVIES \& DAVIES, 1963).

In view of the wide variety of soil solution extraction methods, a question arises regarding whether results obtained by means of different techniques can be compared among each other and what is the best method. While some authors conclude that the results of different methods are comparable (SOUZA et al., 2013) others found the opposite (LUDWIG, et al., 1999). In addition to differences in results among distinct techniques, there are also variations in the same technique; for example, different tensions applied in the sample can change the volume extracted and alter the solutes concentration obtained (GLOAGUEN, et al., 2009).

The uncertainty about the best method of extraction of the soil solution is related mainly to the difficulty of the scientists to separate the water that makes up the soil solution from the one that makes up the diffuse double layer. Therefore, it is extremely necessary to be informed at scientific works how the solution was extracted, so that the results can be better analyzed.

This note does not intend to compare the soil solution extraction methods. We aim to describe an equipment and procedures required to extract the soil solution quickly and economically by centrifugation of deformed soil samples and analyze its application in soils with different granulometry. 


\section{DESCRIPTION}

The necessary equipment to demonstrate the methodology and procedure were standardized in the Chemistry and Fertility of Soil Laboratory at Universidade Federal de Santa Maria in Santa Maria, RS, Brazil. We used a soil storage container and a centrifuge.

The soil storage container was built from a polyvinyl chloride tube - PVC $(5.5 \mathrm{~cm}$ the diameter and $12.0 \mathrm{~cm}$ the length) and a cap compatible to the tube diameter. During the building process, the cap was cut in half in parallel direction to the diameter. On nonhollow portion were performed perforations with diameter of $1 \mathrm{~mm}$ and equidistant (Figure 1b). After punching, the piece was placed at the end of the PVC tube serving as a permeable cover. At $10 \mathrm{~cm}$ PVC tube, the leaked half of the cap was fixed in order to adjust the assembly inside of the centrifuge (item optional according to centrifuge configuration) (Figure 1a, c). Toward to initial filtering of the soil solution, a quantitative filter $(45 \mu \mathrm{m})$ is allocated between the soil and the perforated cover.

The energy to extract the soil solution is applied by centrifugation. This energy can be adjusted in function of G-Force (Equation 1) or mean tension (FREITAS Jr. \& SILVA, 1984) (Equation 2) applied to the sample by the spin movement.

$$
G-\text { Force }=\frac{v^{2}}{R_{i} g}
$$

Where G-Force is the active energy in the soil solution; $\mathrm{v}$ is the velocity of spin movement $\left(\mathrm{m} \mathrm{s}^{-1}\right) ; \mathrm{R}_{\mathrm{i}}$ is the distance from centrifuge central axis to ground surface $(\mathrm{m})$; and $\mathrm{g}$ is the gravitational force $\left(\mathrm{m} \mathrm{s}^{-2}\right)$.

$$
\bar{h}=\frac{w^{2} L\left(3 R_{e}-L\right)}{6 g} \text { where: } L=R_{e}-R_{i}
$$

Where $\bar{h}$ is the mean tension applied on sample $(\mathrm{cm})$; $\mathrm{w}$ is the angular velocity $\left(\mathrm{rad} \mathrm{s}^{-1}\right) ; \mathrm{R}_{\mathrm{e}}$ is the distance from centrifuge central axis to outer end of the soil sample (cm); $\mathrm{L}$ is the distance between extremities of soil sample $(\mathrm{cm})$; and $\mathrm{g}$ is the gravitational force $\left(\mathrm{cm} \mathrm{s}^{-2}\right)$.

Toward to calculate how much energy will be or was applied or what is the centrifuge configuration to apply the energy desired to extract the soil solution, we operate the equations above in Visual Basic language. The "Centrifuge" software, version 1.0, was developed in VB. Net for Windows environment. The Centrifuge 1.0 software might be required by author's e-mail.

We carried out a procedure for extraction the solution from three distinct granulometric soils. The soils were a Latossolo Vermelho distroférrico típico Rhodic Hapludox (RH1), Latossolo Vermelho distrófico típico - Rhodic Hapludox (RH2) and Argissolo Vermelho-Amarelo distrófico típico - Typic Paleudolts (TP) by Brazilian Soil Classification System (Santos et al., 2013) and Soil Taxonomy (USDA, 2014). The granulometric composition in $\mathrm{kg} \mathrm{kg}^{-1}$ of sand, silt and clay were, respectively, $0.13,0.25$ and 0.62 in RH1, $0.45,0.20$ and 0.35 in RH2 and $0.64,0.26$ and 0.10 in TP.

The extraction consisted in adding $0.150 \mathrm{~kg}$ of soil previously dried in air and sieved $(2 \mathrm{~mm})$ in a container - conditioned sample (CS). After, the CS was set to saturate by capillarity in a beaker with distilled water for 24 hours. Then the CS was placed on absorbent paper to drain the excess water for 24 hours (adapted from ELKHATIB et al., 1986). After this period, the extraction of soil solution was performed by centrifugation (Figure 1c). A collecting vessel was attached at the bottom of the CS in order to store the solution drained during the spin movement, it could also be composed of a new cap or plastic bag allocation in the container base.

The centrifuge used had $\mathrm{R}_{\mathrm{e}}$ of $17.9 \mathrm{~cm}$ and $\mathrm{R}_{\mathrm{i}}$ ranging from 11.2 to $12.3 \mathrm{~cm}$ (range depending on the height of sample). The centrifuge was adjusted to work at 1750 rotations per minute during 20 minutes. During the centrifugation process the soil volume decreased because there is a compression of material caused by energy application on the CS. Thus, it was assumed that the maximum soil compaction occurs shortly after the beginning of the centrifugation process. Then, to quantify the mean tension and the G-Force applied, it was considered the height sample after centrifugation process.

To analyze the pore diameter drained by centrifugation, we solved the capillary equation (equation 3) with the mean tension, from equation 2, applied to the samples.

$$
r=\frac{2 \sigma \cos \alpha}{\rho g h}
$$

where $\mathrm{r}$ is the pore radius ( $\mathrm{m}) ; \sigma$ is the surface tension $\left(\mathrm{N} \mathrm{m}^{-1}\right) ; \alpha$ is the contact angle $\left(^{\circ}\right) ; \rho$ is the specific water mass $\left(\mathrm{Mg} \mathrm{m}^{-3}\right)$; $\mathrm{g}$ is the acceleration of gravity $\left(\mathrm{m} \mathrm{s}^{-2}\right)$ and $\mathrm{h}$ is mean tension $(\mathrm{m})$.

The extracted soil solution volume ranged from $25 \mathrm{ml}$ to $30 \mathrm{ml}$ (Table 1). This variation is given by the granulometric difference among soils. The higher clay content of RH1 and RH2 was fundamental for higher initial gravimetric moisture content. However, in soil RH1, the clay content also favored a lower volume of solution extracted, since the G-force and mean tension was similar between RH1 and RH2. Soils with low or high clay content, as in TP and RH1, higher mass of soils must be used to obtain the same solution volume without change the extraction energy. 
The variation of the energy applied at samples is because of higher density and lower volume of the TP soil compared to the soils RH1 and RH2. The lower soil volume results in lower sample height and larger $\mathrm{R}_{\mathrm{i}}$, so at the same spin movement $(1750 \mathrm{rpm})$ the $\mathrm{G}$-force was higher and the mean tension was lower than other soils
(RH1 and RH2). Thus, we suggest that when working with discrepant granulometric soils, the soil mass or the spin movement are adjusted to result the same energy applied to the samples.

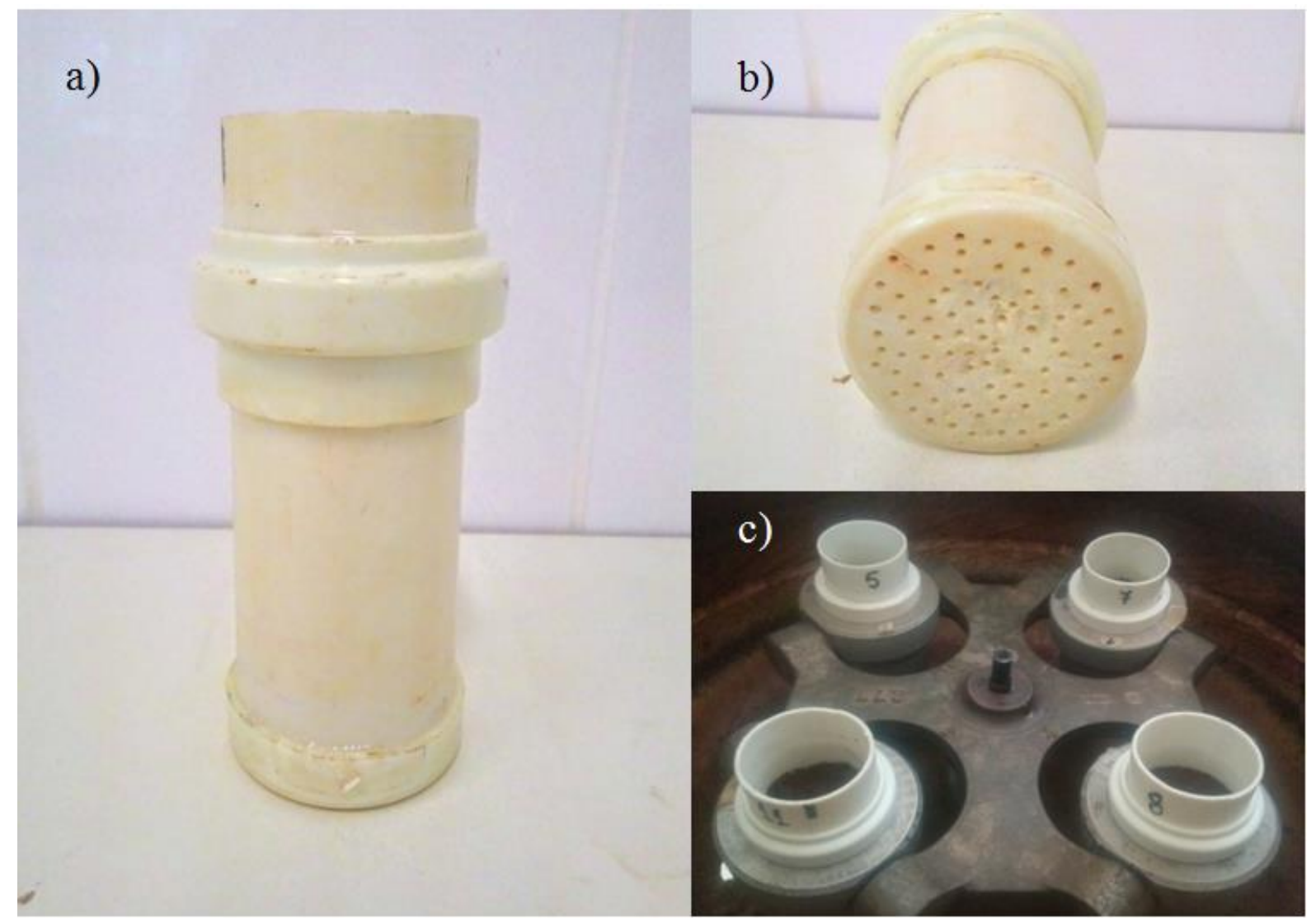

Figure 1 - a) Soil storage container. b) Perforations for soil solution extraction. c) Arrangement of samples for centrifugation process.

Table 1 - Initial and final characteristics, and soil solution extracted by soil types subject to different extraction energy.

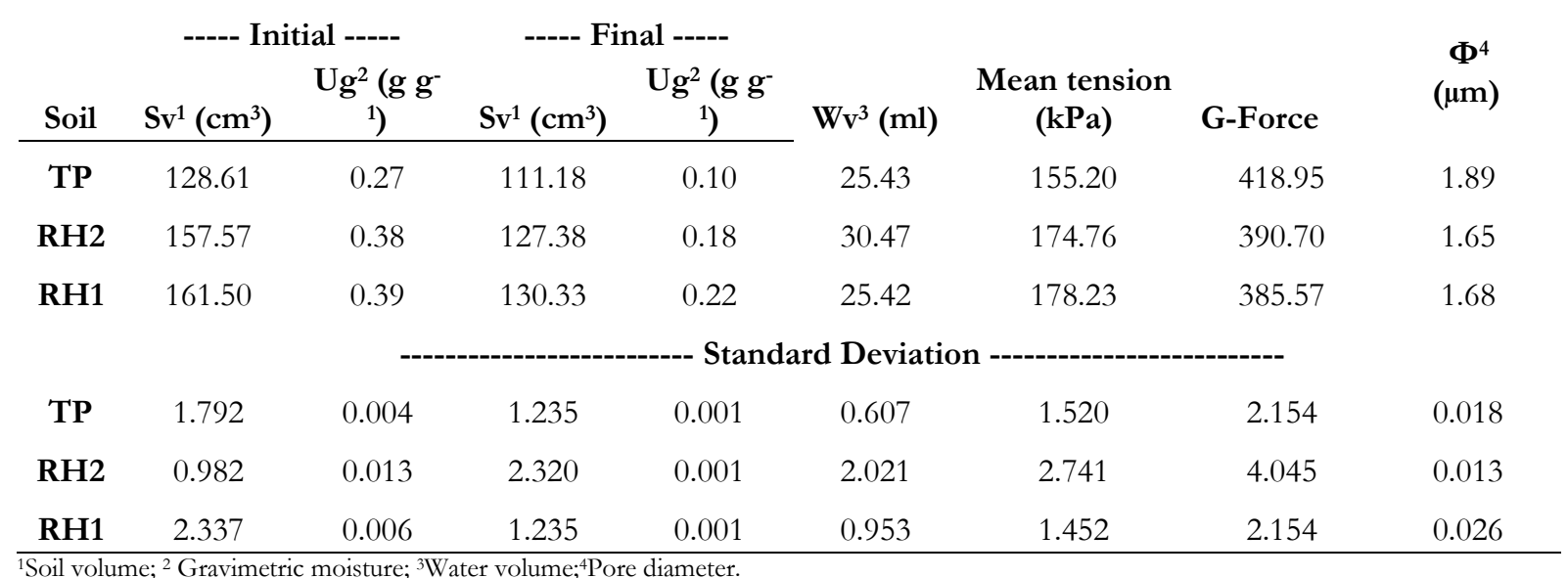


When different extraction energies were applied to obtain soil solution, although using the same extraction method, it is difficult to compare results. The energy applied in this process is connected directly with proximity between soil solution extracted and double diffuse layer of the colloidal fraction of soil. Thus, change on extraction energy cause ion concentration difference among extracted solution (GLOAGUEN, et al., 2009).

The pore diameter drained was lesser in $\mathrm{RH} 1$ and $\mathrm{RH} 2$, in consequence from higher mean tension (Table 1) applied. The drainage of smaller pores size may suggest the water extraction from double diffuse layer. However, considering the thickness diffuse double layer can reach $4 \times 10^{-2} \mu \mathrm{m}$ (BOLT \& BRUGGENWERT, 1976), certainly the applied energy able to drain pores with diameter greater than $1.65 \mu \mathrm{m}$ is insufficient to extract water from the diffuse double layer.

\section{CONCLUSION}

This centrifugation methodology and the Centrifuge 1.0 software are useful tools which set a quickly and economically method to obtain the soil solution. Ultimately, we insist that authors must write clearly the way that soil solution was obtained for their study.

\section{REFERENCES}

BOLT, G. H. \& BRUGGENWERT, M. G. M. Soil Chemistry. A. Basic Elements. Elsevier, Amsterdam, NL. 1976.

CARMO, D. L.; SILVA, C. A.; LIMA, J. M.; PINHEIRO, G. L. Electrical conductivity and chemical composition of soil solution: comparison of solution samplers in tropical soils. Revista Brasileira de Ciência do Solo, v. 40, e0140795, 2016. DOI: 10.1590/18069657rbcs20140795

DAVIES, B. E. \& DAVIES, R. J. A simple centrifugation method for obtaining small samples of soil solution. Nature, v. 198, p. 216-217, 1963. DOI:10.1038/198216a0.
ELKHATIB, E. A.; BENNETT, O. L.; BALIGAR, V. C.; WRIGHT, R. J. A centrifuge method for obtaining soil solution using an immiscible liquid. Soil Science Society of American Journal, v. 50, p. 297 - 299, 1986. DOI: 10.2136/sssaj1986.03615995005000020008x.

FREITAS JÚNIOR, E.; SILVA, E. M. Uso da centrífuga para determinação da curva de retenção de água do solo, em uma única operação. Pesquisa Agropecuária Brasileira, v. 19, p. 1423-1428, 1984.

GLOAGUEN, T. V.; PEREIRA, F. A. C.; GONÇALVES, R. A. B.; PAZ, V. S. Sistema de extração seqüencial da solução na macro e microporosidade do solo. Revista Brasileira de Engenharia Agricola e Ambiental, v. 13, p. 544 - 550, 2009. DOI: 10.1590/S1415-43662009000500006.

LUDWIG, B.; MEIWES, K. J.; KHANNA, P.; GEHLEN, R.; FORTMANN, H.; HILDEBRAND, E. E. Comparison of different laboratory methods with lysimetry for soil solution composition - experimental and model results. Journal of Plant Nutrition and Soil Science, v. 162 , p. 343 - 351, 1999. DOI: 10.1002/(SICI)15222624(199906)162:3<343::AID-JPLN343>3.0.CO;2-E.

SANTOS, H. G.; JACOMINE, P. K. T.; ANJOS, L. H. C.; OLIVEIRA, V. A.; OLIVEIRA, J. B.; COELHO, M. R.; LUMBRERAS, J. F.; CUNHA, T. J. F. Sistema brasileiro de classificação de solos. 3a ed. Embrapa Solos, Rio de Janeiro, 2013.

SOUZA, E. R.; MELO, H. F.; ALMEIDA, B. G.; MELO, D. V. M. Comparação de métodos de extração da solução do solo. Revista Brasileira de Engenharia Agrícola e Ambiental, v. 17, p. 510-513, 2013. DOI: 10.1590/S1415-43662013000500007.

STRECK, C. A.; REINERT, D. J.; REICHERT, J. M.; RHEINHEIMER, D. S.; AITA, C.; PUJOL, S. B. Extração da solução do solo in situ e análise de nitrato e nitrito por dois métodos... In: V Reunião Sul-Brasileira de Ciência do Solo, Florianópolis, 2004.

UNITED STATES DEPARTMENT OF AGRICULTURE - USDA, Keys to Soil Taxonomy. $12^{\text {th }}$. Ed. Government Printing Office, Washington, DC, P. 372, 2014. 